\title{
Analysis of Early Childhood Stimulation Training Program through the Detection of Child Growth and Development Activities on the Ability of School Cadres
}

\author{
Dewi Modjo ${ }^{1}$, Andi Akifa Sudirman ${ }^{1}$ \\ ${ }^{1}$ Nursing Science, Muhammadiyah University of Gorontalo, Indonesia
}

\begin{abstract}
Stimulation is an activity to stimulate the basic abilities of children aged 0-6 years so that the child grows and develops optimally. Every child needs to receive regular stimulation as early as possible and continuously at every opportunity. This study aims to determine the analysis of the Stimulation Training Program for children through the Detection of Child's growth and development on the ability of school cadres to stimulate early childhood growth and development. This research method is a quantitative study using a quasi-experimental design. The type of sampling is two-stage random sampling. The sample of this research is school cadres of Early Childhood Education (PAUD) consisting of 16 Schools for Playgroups (KB), 32 Schools of Right-Kindergarten (TK), and 2 Schools of Child Care (TPA) in the Limboto Health Center Work Area. The results showed that there was a significant and significant effect of development detection training on the ability of school cadres to simulate child growth. The ability of school cadres to stimulate children's growth and development has increased knowledge before and after training. There is a significant and significant effect of developmental detection training on the ability of school cadres to stimulate child development. It is necessary to empower cadres evenly and periodically by related parties (the Health Office and Pusekesmas) in order to improve the growth and development screening skills carried out by school cadres. It is also hoped that this will improve the child's health status so that the child can grow and develop properly.
\end{abstract}

Keywords: Childhood, Stimulation, Growth, Development

Received: October 22, 2020

Received in Revised: October 30, 2020

Accepted: November 2, 2020

\section{Introduction}

Early detection of child development is an activity or examination to find early growth irregularities in toddlers and preschool children. By finding irregularities or problems with child development early, interventions will be easy to do, health workers also have the time to take appropriate action plans, especially to involve mothers and families. The stage of child development is divided into two. Growth is a physical change that can be measured and development is the addition of the ability to structure and function of a more complex body (Rosengren et al., 1991; Hills et al., 2007).

Early detection of growth irregularities, namely to determine or find malnutrition and micro or macrocephaly status (Sly et al., 2008; Utami, 2016). The types of activities carried out include measuring body weight for height (BW / TB) and measuring the child's head circumference (LKA). Early detection of developmental deviations, namely to determine the child's developmental disorders (delays), visual impairment, and hearing impairment. The types of activities carried out include screening or examinations using the Developmental Pre-Screening Questionnaire (KPSP), Visibility Test (TDL), and Hearing Power Test (TDD). Early Detection of Growth Irregularities is carried out at all service levels. 
Early Detection of Emotional mental disorders is an activity or examination to find early mental-emotional problems, autism, attention deficit disorder, and hyperactivity in children, so that intervention can be taken immediately (Sobanski et al. 2010; Shaw et al., 2014; Ismawati et al. , 2020). If mental-emotional deviations are detected too late, the intervention will be more difficult and this will affect the development of children (Hertzman \& Wiens, 1996; Yoshikawa et al., 2012).

Research on growth and development detection training has existed before, but the research to be conducted is different from that research. Research that has been conducted by Dewi Maritalia on the analysis of the implementation of the simulation program, detection, and early intervention for growth and development (SDIDTK) for toddlers and preschoolers at the Semarang city health center. The difference between this study and the research conducted by Dewi is that this study aims to identify mental, emotional, growth-development status problems and attention deficit disorders and hyperactivity in pre-school children in the Kindergarten Work Area of Puskemas (Community Health Center) Rantang. In contrast to the research conducted that analyzes the effectiveness of development and development detection training both in terms of early detection of growth, early detection of development and detection of mental-emotional deviations from school cadres in stimulating growth and development in preschool children. This study aims to determine the analysis of the Child Stimulation Training Program through the Detection of Child Growth and Development on the ability of school cadres to stimulate early childhood growth and development.

\section{Methods}

This research is a quantitative study using a quasi-experimental design that provides treatment or intervention to the research subjects, then the effect of the treatment is measured and analyzed. The research design used was the pre post-test group design approach.

The sample of this research is school cadres of Early Childhood Education (PAUD) consisting of 16 schools for Playgroups (KB), 32 Schools of Right-Kindergarten (TK), and 2 Schools of Child Care (TPA) in the Limboto Health Center Work Area. that meet the inclusion and exclusion criteria set by the researcher. The sampling technique used in this research is probability sampling, which is a sampling technique that provides equal opportunities or opportunities for each element or member of the population to be selected as samples. The type of sampling is two stages of random sampling.

\section{RESULTS AND DISCUSSION}

\section{Respondent Characteristics}

The characteristics of the respondents described in this study include the distribution of respondents based on age and previous training. For more details, see the following table:

Table 1. Distribution of Respondents Characteristics by Age, and Previous Training

\begin{tabular}{|c|l|c|c|}
\hline \multicolumn{1}{c}{ No } & Respondent Characteristics & \multicolumn{1}{c}{ Frequency } & Percentage \\
\hline $\mathbf{1}$ & Age & 3 & $20 \%$ \\
& 20-29 years & 6 & $40 \%$ \\
& 30-39 years & 6 & $40 \%$ \\
\hline \multirow{2}{*}{} & 40-59 years & 3 & \\
& Previous Training & 12 & $20 \%$ \\
& Never Joined & & $80 \%$ \\
\hline
\end{tabular}

Source: Processed Primary Data 2020 
A number of tables presented above describe the characteristics of respondents related to the distribution of respondents based on age, most of them at the age of 30-39 years, namely 6 people (40\%) and 40-59 years, namely 6 people (40\%), while the distribution of respondents based on training previously, most of the $12(80 \%)$ school cadres had attended previous training.

This study aims to analyze the effectiveness of growth and development detection training on the ability of school cadres to stimulate growth and development in preschool children (5-6 years) in the Limboto Health Center, Gorontalo District. This study will present an analysis of variable frequency distribution data (the ability of school cadres before and after training on early detection of growth and development), as well as an analysis of the relationship between variables.

\section{Frequency Distribution Analysis}

In the following section, data analysis of the frequency distribution of respondents will be presented before and after being given training in early detection of growth and development.

Table 2. Distribution of Average Value of School Cadres Ability Before and After being given Early Detection Training for Growth and Development

\begin{tabular}{|c|l|c|c|}
\hline \multirow{2}{*}{ No. } & \multicolumn{1}{|c|}{ Variable } & Mean & $\begin{array}{c}\text { Standard } \\
\text { Deviation }\end{array}$ \\
\hline \multirow{2}{*}{1} & Preschool Child Growth Simulation & & \\
\cline { 2 - 4 } & Before & 5,60 & 1,92 \\
\cline { 2 - 4 } & After & 7,40 & 1,68 \\
\hline 2 & $\begin{array}{l}\text { Preschool Child Development } \\
\text { Simulation }\end{array}$ & & \\
\cline { 2 - 4 } & Before & 3,60 & 1,45 \\
\cline { 2 - 4 } & After & 5,93 & 1,83 \\
\hline
\end{tabular}

Source: Processed Primary Data 2020

The growth simulation variable of preschool children before training on early detection of growth and development is 5.60 with a standard deviation of 1.92. Meanwhile, the growth simulation value of preschool children after treatment is 7.40 with a standard deviation of 1.68. And on the variable of the development simulation of preschool children before training on early detection growth and development is 3.60 with a standard deviation of 1.45 . Meanwhile, the simulation value of the development of preschool children after training on early detection of growth and development is 4.93 with a standard deviation of 1.83 .

\section{Relationship Distribution Analysis}

In this analysis, the Dependent T-Test (Paired Sample T-Test) is used to determine whether there is an influence between the independent and dependent variables.

Table 3. Results of the Analysis of the Effect of the Growth and Development Detection Training on the Ability of School Cadres

\begin{tabular}{|c|l|c|c|c|c|c|}
\hline No & Variable & Mean & SD & SE & P-value & n \\
\hline \multirow{2}{*}{1} & $\begin{array}{l}\text { Preschool Child Growth } \\
\text { Simulation }\end{array}$ & & & & & \\
\cline { 2 - 7 } & Before & 5,60 & 1,92 & 0,49 & 0,002 & 15 \\
\cline { 2 - 7 } & After & 7,40 & 1,68 & 0,43 & & \\
\hline 2 & $\begin{array}{l}\text { Preschool Child } \\
\text { Development Simulation }\end{array}$ & & & & & \\
\hline
\end{tabular}




\begin{tabular}{|l|l|l|l|l|l|l|}
\hline & Before & 3,60 & 1,45 & 0,37 & 0,000 & 15 \\
\cline { 2 - 7 } & After & 5,93 & 1,83 & 0,47 & & \\
\hline
\end{tabular}

Source: Processed Primary Data 2020

From the results of statistical tests on the growth simulation variable of preschool children, the p-value is 0.002 and it can be seen that the mean difference in the average is -1.800 with a standard deviation of 1.78. So it can be concluded that there is a significant and significant effect of development detection training on the ability of school cadres to simulate child growth.

In the statistical test results of the variable simulation of the development of preschool children, the p-value is 0.000 and the mean difference is -2.333 with a standard deviation of 1.63. So it can be concluded that there is a significant and significant effect of development detection training on the ability of school cadres to stimulate child development.

Stimulation is an activity to stimulate the basic abilities of children aged 0-6 years so that the child grows and develops optimally. Every child needs to receive regular stimulation as early as possible and continuously at every opportunity. Stimulation of child development is carried out by mothers and fathers who are the closest to the child, substitute mother/child caregiver, other family members and community groups in their respective households and in their daily life. (Ministry of Health of the Republic of Indonesia, 2010).

Stimulation is done with love and affection. Always show good attitude and behavior, because children will imitate the behavior of those closest to them. Provide stimulation according to the child's age group. Perform stimulation by inviting children to play, sing, be varied, fun, without coercion and there is no punishment or yelling whether the child wants to do or does not want to do the activities they are trained to do. The simulation variable of the development of preschool children before training on early detection of growth and development is 3.60 with a standard deviation of 1.45 . Meanwhile, the simulation value of the development of preschool children after training on early detection of growth and development is 4.93 with a standard deviation of 1.83 . The simulation of the growth of preschool children obtained a p-value of 0.002 and it can be seen that the mean difference in the mean is -1.800 with a standard deviation of 1.78 . So it can be concluded that there is a significant and significant effect of development detection training on the ability of school cadres to simulate child growth. The simulation of the development of preschool-aged children obtained a p-value of 0.000 and it can be seen that the mean difference in the mean is -2.333 with a standard deviation of 1.63 . So it can be concluded that there is a significant and significant effect of development detection training on the ability of school cadres to stimulate child development.

Lack of stimulation can lead to irregularities in child development and even persistent disturbances. The basic abilities of children that are stimulated by directed stimulation are gross motor skills, fine motor skills, speech and language skills as well as social skills and independence. The stimulation of child development aims to help children reach an optimal level of development according to their age. This activity includes various activities to stimulate children's development, including movement exercises, talking, thinking, independent, and socializing (Ministry of Health of the Republic of Indonesia, 2010).

\section{Conclusion}

There is a significant and significant effect of development detection training on the ability of school cadres to simulate child growth. The ability of school cadres in stimulating children's growth and development has increased in knowledge before and after being given training, so 
it is hoped that school cadres will know how to report if there are children with growth and development problems or deviations. There is a significant effect of developmental detection training on the ability of school cadres to stimulate child development.

\section{References}

Departemen Kesehatan Republik Indonesia. (2010). Pedoman pelaksanaan stimulasi, deteksi, dan intervensi dini tumbuh kembang. Jakarta: Depkes RI. Available from: https://www.academia.edu/35598519/PEDOMAN_PELAKSANAAN_Stimulasi_De teksi_dan_Intervensi_Dini_Tumbuh_Kembang_Anak_Stimulasi_Deteksi_dan_Inter vensi_Dini_Tumbuh_Kembang_Anak.

Hertzman, C., \& Wiens, M. (1996). Child development and long-term outcomes: a population health perspective and summary of successful interventions. Social science \& medicine, 43(7), 1083-1095.

Hills, A. P., King, N. A., \& Armstrong, T. P. (2007). The contribution of physical activity and sedentary behaviours to the growth and development of children and adolescents. Sports medicine, 37(6), 533-545.

Ismawati, I., Riana, H., \& Haslan, H. (2020). Description of Mother's Knowledge About the Growth and Development of Toddlers Ages 1-5 Years at the Village Maternity Cottage. Journal La Medihealtico, 1(4), 8-14.

Rosengren, K. S., Gelman, S. A., Kalish, C. W., \& McCormick, M. (1991). As time goes by: Children's early understanding of growth in animals. Child Development, 62(6), 1302-1320.

Shaw, P., Stringaris, A., Nigg, J., \& Leibenluft, E. (2014). Emotion dysregulation in attention deficit hyperactivity disorder. American Journal of Psychiatry, 171(3), 276-293.

Sly, P. D., Boner, A. L., Björksten, B., Bush, A., Custovic, A., Eigenmann, P. A., ... \& Lemanske, R. F. (2008). Early identification of atopy in the prediction of persistent asthma in children. The Lancet, 372(9643), 1100-1106.

Sobanski, E., Banaschewski, T., Asherson, P., Buitelaar, J., Chen, W., Franke, B., ... \& Stringaris, A. (2010). Emotional lability in children and adolescents with attention deficit/hyperactivity disorder (ADHD): clinical correlates and familial prevalence. Journal of Child Psychology and Psychiatry, 51(8), 915-923.

Utami, S. (2016). Midwives Performance in Early Detection of Growth and Development Irregularities of Children Based on Task Commitment. International Journal of Evaluation and Research in Education, 5(4), 300-305.

Yoshikawa, H., Aber, J. L., \& Beardslee, W. R. (2012). The effects of poverty on the mental, emotional, and behavioral health of children and youth: implications for prevention. American Psychologist, 67(4), 272. 